\title{
Pragmatisme og "practice turn"
}

Praksisorientering er en af de mest centrale bestanddele af den filosofiske pragmatisme. Ved praksis forstår pragmatismen en samling af praksisser, i hvilke forskellige former for handlen, bl.a. også den fremstillende gøren og den formålsrettede handlen, anses for at være forbundne med såvel aktører, rutiner og habitualiseringer som ting og værktøjer i livsverdensmæssige og videnskabelige sammenhænge. Pragmatismen har med sin version af en praksisteori altid vendt sig imod de negative konsekvenser af den platonisk-aristoteliske opfattelse af teori, praksis og poeisis, idet den nemlig resulterer i en ensidig udmærkelse af det kontemplative forhold til verden og en ligeså ensidig nedvurdering af det produktive og aktive forhold mellem menneske og verden. Særlig John Dewey har foretaget en nyvurdering af både praksis' og poeisis' status og har kritiseret de negative konsekvenser af den vedvarende indflydelse af den platoniske og aristoteliske underordning af praksis og poeisis under teoriens førerstilling. I den indflydelsesrige aristoteliske udgave skelnes som bekendt mellem praksis (menneskelig handlen som sædelig praksis), teori (erkendelsen af de sidste begrundelser og årsager) og poeisis (den fremstillende gøren). Teori bliver, ifølge Aristoteles, udøvet for sin egen skyld, og det menneske, der udøver teori, opfylder bedst det i mennesket anlagte potentiale. Det gode liv som praksis er ifølge Aristoteles selvfølgelig ikke udelukkende muligt som teoretisk livsførelse, men alligevel er den teoretiske holdning den, der for Aristoteles udmærker det gode liv som praksis i særlig grad. Den fremstillende poietiske handlen står hos Aristoteles i den nedre ende af hierarkiet af livsførelser. Nu er det imidlertid ikke først pragmatismen, der har kritiseret og ændret det aristoteliske hierarki af menneskelig selvforståelse og dets forhold til verden. Rehabiliteringen af praksis og nyfortolkninger af praksisbegrebet har talrige rødder i den filosofiske tradition og rækker fra opvurderingen af livspraktisk klogskab hos Montaigne, over Marx' og Neo-Marxismens politisk praksisbegreb til anerkendelsen af livsverdenen som den uomgængelige baggrund for vores viden i Husserls fænomenologi eller Heideggers eksistensfilosofi. I alle disse traditioner hersker der dog på ingen måde enighed om, hvad det er, der skal gælde som praksis 
og hvilke konsekvenser den nye opmærksomhed på praksissammenhænge udløser.

Det samme gælder også for den aktuelle såkaldte "practice turn". Begrebet "practice turn" dækker over flere forskellige teorier: f.eks. forskellige tilgange i Science and Technology Studies (STS), bl.a. Bruno Latours Aktør-Netværk-Teori eller Andrew Pickerings videnskabsstudier af mødet mellem det humane og det nonhumane, Bourdieus praksissociologi og Laurent Thevenots såkaldte nypragmatisme men også nyfortolkninger af Heidggers eksistensfilosofi. På et mere generelt niveau kan man sige at "practice turn" og praksisteorier som genstand har "kropsligt forankrede og materielt sammenflettede praksisser som er centralt organiserede omkring fælles praktiske forståelser" (Schatzki 2001b: 12). Jeg vil i det følgende hovedsageligt anvende "practice turn" som baggrund for fremstillingen af pragmatismen uden en detaljeret analyse af de teorier, der sammenfattes under paraplybegrebet "practice turn" eller den praktiske vending.

Med dette bidrag forsøger jeg at vise, at den klassiske pragmatisme - og her begrænser jeg mig til Deweys pragmatisme - for det første er i stand til at yde et væsentligt systematisk bidrag til forståelsen af praksis, og for det andet, at Deweys pragmatisme er en radikalisering af den omtalte nyvurdering af praksis og praksisser. Dewey opfordrer både filosofien og socialvidenskaberne til ikke blot at bestemme forholdet mellem praksis og teori på ny, men derimod også at inddrage poeisis, den fremstillende gøren, der traditionelt er forbeholdt natur- og ingeniørvidenskaberne, på en ny måde. Det betyder et radikalt skift fra en kontemplativ videnskabsforståelse til en aktiv og producerende videnskabsforståelse, hvor filosofien eller socialvidenskaberne træder ind i et producerende og ikke kun reflekterende samarbejde med teknologierne og ingeniørvidenskaberne. Filosofiens rolle og selvforståelse bliver altså forandret i retning af at filosofi ikke kun analyserer verden men selv bidrager til forandring af verden. Hermed afskiller Deweys pragmatisme sig tydeligt fra andre praksisteorier.

I den første del vil jeg give en kort indføring i "practice turn", for så at fremstille Deweys pragmatisme og her gå ind på ligheder med "practice turn". Hvad man skal forstå under praksisser fra et pragmatisk synspunkt, der tager udgangspunkt i Dewey, vil jeg tydeliggøre i anden del med en analyse af erfaringsbegrebet. Afsluttende vil jeg i en tredje del forklare konsekvenserne af det radikale primat over teori, som praksis tilkendes $i$ Deweys pragmatisme. 


\section{Den pragmatiske position}

Som allerede antydet, er der ingen enhedslig praksisteori hverken i socialvidenskaberne og STS eller i filosofi. Theodore Schatzki, Karin KnorrCetina og Eike von Savigny har i deres antologi med titlen The Practice Turn in Contemporary Theory (2001a) samlet talrige teoriansatser, som delvis er helt forskelligt udformet, men dog alle i centrum har undersøgelsen af et felt af praksisser, f.eks. det sociale som felt af praksisser. Som Andreas Reckwitz (2002) bemærker, er denne bestemmelse af det sociale som bestemt af praksisser på sin vis en trivialitet, når man undlader at definere, hvilke praksisser der menes og hvilken status disse praksisser har. Således har Reckwitz lavet et forslag til en systematisering af "practice turn", eller som han kalder det, af "practice theory" (Reckwitz 2002) i socialvidenskaberne. Han afgrænser først praksisteorierne fra de socialvidenskabelige ansatser, der postulerer det sociales homogene logik og går ud fra homo oeconomicus eller homo sociologicus. Teorier som rational choice-teorien eller Talcott Parsons strukturfunktionalisme går alle ud fra, at der er et princip, som er overordnet praksisserne og kan forklare handlinger og strukturer. Praksisteorien derimod

"reviderer det hyperrationelle og intellektualiserede billede af det menneskelige handlingsliv og det sociale som præsenteres af klassiske og høj-moderne teorier om det sociale. Praksisteori 'decentrerer' bevidstheden, tekster og samtale. Samtidig sætter den kropslige bevægelser, ting, praktisk viden og rutiner i centrum." (Reckwitz 2002: 259).

Dermed afgrænser Reckwitz også praksisteorien fra tre kulturelle socialteorier: den kulturelle mentalisme, den kulturelle tekstualisme og intersubjektivitetsteorierne. Disse tre kulturelle socialteorier beskriver og forklarer nemlig det sociale, idet de går ud fra forskellige men uomgængelige sociale byggesten, som selv igen skal gøre praksisser forstålige. Eksempelvis udgør diskurser og tekster i den kulturelle tekstualisme explanandum for den explanans, der skal forklares, det sociale. Reckwitz' analyse af disse kulturelle socialteoriers udgangspunkt $i$ et fast explanandum kan overføres til filosofien og det bliver i denne artikel vist med udgangspunkt i den pragmatiske kritik af den bagvedliggende 'foundationalism', der er kendetegnende for disse kulturelle socialteoriers teoriforståelse.

Centralt for praksisteorien både hos Reckwitz og i de fleste andre artikler $\mathrm{i}$ antologien The Practice Turn in Contemporary Theory er, at undersøgelsen 
af praksisser overskrider grænsen mellem krop, materialitet og tingsverden på den ene side og handlinger, mentale indstillinger og aktørers normer på den anden side. Med materialitetsteorier som dem af Michel Callon og Bruno Latour bliver det interaktionistiske paradigme opblødt, og ikke kun menneskelige aktører, men også ting bliver anset som handlingsbærere $\mathrm{i}$ overensstemmelse med princippet om symmetri. Pragmatismen har ganske vist ikke forklaret materialitetstemaet ligeså eksplicit som dele af STS, men særligt Deweys handlingsteori peger hen på denne bredere forståelsesramme, der overskrider den lingvistiske forståelse af det sociale og kulturelle. Det er også vigtig at fremhæve, at den klassiske pragmatisme, dvs. Charles Sanders Peirce, William James, John Dewey og George Herbert Mead, har øvet en ikke ubetydelig indflydelse på udviklingen af nogle af de teorier, der er samlet under begrebet "practice turn", f.eks. Garfinkels etnometodologi. I den nyeste tid er det særligt Bruno Latour, der refererer til og benytter sig af John Deweys pragmatisme (Latour 2005b).

I den følgende fremstilling af det, som kan sammenfattes som pragmatisk tænkning, vil jeg koncentrere mig om de elementer, der forklarer praksisbegrebet. Med pragmatisk tænkning har jeg dannet en idealtypisk pragmatisme, som bygger mest på Deweys version og inkluderer nogle elementer af Rortys epistemologikritik. Fremstillingen er inspireret af Richard Bernsteins præsentation af den 'pragmatiske etos' (Bernstein 1989), men her med fokus på den forandring af selve den filosofiske praksis, som jeg ser som den mest relevante og innovative konsekvens af den pragmatiske praksisforståelse. Alle tre elementer behandler spørgsmålet om praksis: for det første som epistemologisk og metafilosofisk spørgen til, hvilken rolle viden og erfaring har - her med stikordene anti-repræsentationalisme og anti-foundationalism. For det andet som spørgsmålet om videnspraksis under stikordene viden og falllibilisme. Og for det tredje som spørgsmålet om hvilken rolle teori og praksis spiller for vores forståelse af viden.

\section{Anti-repræsentationalisme og anti-foundationalism}

En central bestanddel af pragmatisk teori - og det kan man genfinde både hos klassikeren Charles S. Peirce og hos neopragmatisten Robert Brandom - er kritikken af den traditionelle, repræsentationalistiske forståelse af viden og erkendelse. Kritikken er på den ene side motiveret af de talrige interne problemer, som repræsentationalismen opviser, på den anden side næres kritikken også af den opfattelse, at denne erkendelsesteoretiske po- 
sition hverken kan begribe den videnskabelige praksis eller gavne den i sin udøvelse. Kritikken af repræsentationalismen er ikke helt ny, Hegel har allerede udøvet den over for Kant og hans erkendelsesteoretiske forgængere (Gimmler 2004). I den aktuelle debat betegner 'repræsentationalisme'- for det meste med kritisk hensigt - en erkendelsesteoretisk eller metafilosofisk position, der - helt alment formuleret - går ud fra, at erkendelse er formidlet af forestillinger. Rorty giver en meget pointeret fortolkning af repræsentationalismeproblematikken idet han kombinerer den med en kritik af 'foundationalism'. Rorty anvender begrebet repræsentationalistisk om alle erkendelsesteoretiske positioner, der, som han kalder det, arbejder med en "forestillingsforestilling" (Rorty 1990: 76). Forestillingsforestilling betegner dermed etableringen af en erkendelsesmæssig særsfære, som sikrer at genstanden er begribelig, er begrebsligt identificerbar og dermed kan tilskrives en sandhedsværdi. Målet for repræsentationen af bevidsthedsindhold er at opnå propositionel viden, der tilsvarende er struktureret diskursivt. Om denne afvisning af repræsentationalismen er de fleste af teorierne med etiketten "practice turn" enige. I Latours Aktør-Netværks-Teori dukker f.eks. afvisning af den repræsentationalistisk forståelse af viden op i skiftet fra "matters of fact" til "matters of concern" (Latour 2005a: 87f.). Målet for en undersøgelse er ikke at repræsentere verden, men på interessant vis at finde den problematiske konstellation af aktører, der åbner for en ny forståelse af et udsnit af virkeligheden.

Rorty retter både sin kritik af repræsentationalismen mod de realistiske varianter af at finde og de antirealistiske ansatser til at lave erkendelsesgenstande. Denne dobbelte stødretning kan kun forstås i sin radikalitet, hvis man også tager højde for sammenkoblingen af repræsentationskritikken og kritikken af foundationalism. Ved foundationalism forstår Rorty (Rorty 1997) alle de positioner, der går ud fra, at selvom man ikke kan opnå vished gennem erkendelsesgenstandene selv, må denne vished kunne sikres af en sfære, der udmærker sig ved at fundere erkendelsen. Denne sfære kan være en mental særsfære (Descartes) eller - for tiden mere en vogue - en specifik logik, med hvilken konstruktionen af erkendelsesgenstande og deres teoretiske forståelse kan ske. Dette gælder for talrige varianter af socialkonstruktivismen. Her er en sammenligning med Bourdieu nærliggende. Han afgrænser sig ganske vist i sine Pascalian Meditations (Bourdieu 2000) eftertrykkeligt fra de socialteorier, der hævder et harmonisk mønster af socialintegration ( $\mathrm{fx}$ Habermas), men bygger samtidig sin egen teori på en logik som tager udgangspunkt i distinktioner og kampe om sociale, 
kulturelle, økonomiske og symbolske kapitalformer. Om denne logik igen selv er foranderlig og skal forstås som idealisering af en bestemt kontekst af praksisser, er ikke noget, Bourdieu helt gennemreflekterer. Set fra radikalpragmatikeren Rortys synspunkt er en sådan søgen efter en begrundelse af videnskrav, der ikke længere har rod i bestemte sociale eller kulturelle praksisser, men enten ontologisk går forud for disse eller universalistisk transcenderer dem, problematisk (Rorty 1996). Og her ville Dewey være helt enig med Rorty. Pragmatismen løsriver sig såvel fra forestillingsforestillingen som fra absolutte begrundelseskrav og ser hverken målet med erkendelsesprocesser som liggende $i$ afbildningen af virkeligheden eller $i$ afdækningen af den struktur eller logik, der funderer virkelighedskonstitutionen. Det er ikke et stykke af verden som korresponderer med viden, men snarere en kontrolleret, målrettet kunnen, der anticiperer et resultat.

\section{Viden og fallibilisme}

Baggrunden for den pragmatiske forståelse af viden og erkendelse er skabt af et skifte væk fra det kontemplative forhold mellem subjekt og objekt. Dermed bliver den teoreticistiske fiksering af den erkendende, som en der står betragtende over for erkendelsesgenstanden, opløst til fordel for en handlingsrelation, der ligger logisk og tidmæssigt forud for forholdet mellem den erkendende og det, der skal erkendes: " For tingene", siger Dewey i sin kritik af intellektualismen, "er i langt højere grad genstande, der håndteres og benyttes, der virkes ind på eller handles med, der nydes og udholdes, mere end genstande for erkendelse. De er ting, som haves, før de er ting, som erkendes"(Dewey 1988: 28). Handlinger er konceptualiseret sådan, at de er indlejret $i$ et net af erfaringer - erfaringer, der er sedimenteret til videnskontekster og beskrivelsesverdener, som igen besidder en betydningskonstitutiv funktion. Dette bliver særlig tydeligt på hverdagsområdet. Den hverdagsmæssige livsverden er snarere kendetegnet ved det, som fænomenologen Alfred Schütz har kaldt den naturlige indstilling. Den største del af alle handlinger og hændelser forventer vi i hverdagen med al selvfølgelighed, fx at lyskurven skifter farve fra rød over gul til grøn, at blomsten er afblomstret næste dag, eller at naboen hilser venligt. Ethvert brud med denne forventelige livsverden har først irritation, men dernæst ofte også en kritisk undersøgelse og eksperimenteren til følge, som i den videnskabelige praksis udøves institutionaliseret og kontrolleret. Løsningen af hverdagsproblemer og den videnskabelige praksis adskiller sig for pragma- 
tister altså gradvist, men ikke absolut. Vice versa er videnskaberne jo også i deres normalvidenskabelige form kendetegnet af indøvede handlinger og vaner. Men overgangene mellem en indøvet hverdag og en eksperimenterende indstilling er flydende. ${ }^{1}$ Væsentligt ved Deweys vidensbegreb er at det forbinder viden med handling; og at handling både er sproghandlen og poietisk, fremstillende handlen. Indsnævringen af vidensbegrebet til propositionel viden bliver dermed ophævet. Med begge typer af handlen forandrer vi verden, og hver handling er derfor et eksperiment og de to handlingstyper er kun gradvist forskellige. Derfor antager pragmatismen, at enhver viden, som opnås i sådanne handlingsrelationer, aldrig definitivt kan gælde som sand, og altså er fejlbarlig.

\section{Praksis' primat over teori}

Med overgangen fra den teoreticistiske til den praktiske erkendelsesrelation og den vidtrækkende afløsning af repræsentationalismen problematiseres det traditionelle primat som teorien plejer at have over praksis. Teorien som et formål i sig selv erstattes af en teoriforståelse, der er instrumentalistisk. Teorier, begreber og metoder bliver opfattet som praksis' instrumenter, også sproget bliver hos Dewey til et værktøj - eller mere præcist, til et andenordens værktøj. Som "værktøjernes værktøj” (Dewey 1988:134) yder sproget en koordination af handlen, og samtidig bliver værktøjsbrugen - dvs. selve meningen med et værktøj - sedimenteret og fastholdt i sproget. Uden på dette sted at kunne gå nærmere ind på Deweys sprogteori kan man fastholde, at via handlingsbegrebet og en nytolkning af anvendelsen af midler, er sproglig kommunikation og fremstillende handlen afhængige af hinanden og gensidigt bestemmende for hinanden. Denne inddragelse af den fremstillende handlen og dermed også af den materielle tingsverden udgør utvivlsomt en af de vigtigste overensstemmelser mellem pragmatismen og dele af "practice turn", fx AktørNetværk-Teorien af Bruno Latour og Michel Callon. At gøre op med dualismer såsom aktør og struktur eller det humane og det non-humane ligger helt i forlængelse af Deweys pragmatiske praksis- og teoriforståelse.

Den forrang, som praksis har, og som er så vigtig i pragmatismen, skal ikke letfærdigt reduceres til at teori blot skal være til nytte for praksis også selvom nytte set fra pragmatismens synsvinkel ikke er at foragte. Teorien får sine afgørende impulser fra praksis - både fra hverdagsverdenen og fra den videnskabelige praksis. Men dermed er hverken den pragmati- 
ske forståelse af handlen eller af teori reduceret til ren problemløsning. Til forskel fra andre nyere filosofiske ansatser, eksempelvis dekonstruktivismen, har pragmatismen et direkte, normativt formål. At forbedre den videnskabelige, sociale eller politiske praksis er målet med pragmatismen - en politisk holdning, der ofte kaldes naiv. Filosofi og forskning er for Dewey en del af det større eksperiment demokrati; begge felter, videnskab og demokrati bygger på kooperative og udforskende handlinger. Forskningsproces og demokratisk styring er begge kendetegnet ved et intelligent samvirke for at finde løsninger på de problemer, som ikke er defineret på forhånd, men tværtimod bliver afgrænset og formuleret på baggrund af offentligheden (Dewey 1991). Det er snarere en udfordring for teorien end en nedvurdering og underordning under praksispræmisser.

Deweys pragmatisme munder ud i en pragmatisk vending, en forandret grundholdning, der indebærer en instrumentalistisk forståelse af teori og en ikke-kontemplativ verdensrelation, dvs. en grundholdning, der giver afkald på at viden skal funderes af en privilegeret særsfære eller logik, og i stedet anser viden for at være fejlbarlig og situeret i sociale og formidlede praksisser. Forbedringen af disse praksisser gennem det eksperimentelle demokratiske fællesskab er pragmatismens mål, og midlet til dette mål leveres af den eksperimenterende handlen, som er institutionaliseret af videnskaberne og udføres målrettet. Men denne vending har også konsekvenser for filosofiens og teoriens opgave og rolle i samfundet. Deweys præstation består netop i, ikke blot at have kritiseret den klassiske filosofi og dens epistemologi, men også at have tildelt filosofien og de andre videnskaber en plads i det eksperimentelle demokratiske fællesskab - og dermed have fremstillet et praksisprimat, som ikke kunne være mere radikalt. Før jeg undersøger denne nyorientering af filosofi og teori, vil jeg se nærmere på Deweys erfaringsbegreb, for at give et mere konkret billede af de nævnte meta-filosofiske forandringer.

\section{Erfaring}

I den filosofiske tradition har erfaringen inden for rammerne af repræsentationalismen, som ovenfor allerede antydet, i det mindste fra Descartes, Hume, Locke og frem indtaget en privilegeret position i sikringen af sand erkendelse eller viden. Med den sproglige vending, sådan kan udviklingen i hvert fald tolkes, får erfaringsbegrebet på ny en sådan rolle, hvor det skal garantere vores videns karakter af sand erkendelse. Dette garantikrav ven- 
der tilbage i transformeret form, nemlig i den lingvistiske version, i form af sprogets systematicitet og logicitet. Tiltroen til at sproget kan have denne funktion af videnssikring er imidlertid ved at svinde; den sene Wittgenstein og de sprogfilosofiske dekonstruktioner af Donald Davidson står for denne skepsis. Vejen fra erfaring til sprog har ført til en problematisering af en sådan søgen efter vished som sådan og har rejst spørgsmålet om, hvordan erkendelse, viden og sprog kan begribes anderledes. At gribe tilbage til erfaringsbegrebet bliver imidlertid med henvisning til Sellars' analyse af "det givnes myte" (Sellars 1999: 23) hyppigt opfattet som en anakronisme. Sellars griber tilbage til et begreb om erfaring, altså 'experience', som i den angelsaksiske filosofitradition ofte forstås på baggrund af en sensualistisk eller empiristisk erkendelsesteori, nemlig som "direkte erkendelse af verden baseret på observation" (Oxford Companion to Philosophy 1995: 261). Denne naive direkte tilgang til verden, som jo ikke blot konstateres, men derimod netop skal sikre vores empiriske viden, blev, som allerede anført, også afvist af pragmatismen under overskriften kritik af repræsentationalismen.

Men kan erfaringsbegrebet ikke også konceptualiseres på en helt anden måde, idet det nemlig ikke på forhånd stilles over for den epistemologiske bevispligt? Og hvad kan en sådan nybestemmelse give? Kan det lade sig gøre, med et ikke-repræsentationalistisk erfaringsbegreb, at konceptualisere en interaktion med verden, som på samme tid indfanger verdens genstridighed og den handlendes kreativitet og som ikke falder tilbage i myten om det givne? Denne ansats, at gøre erfaring og materialitet teoretisk konceptualiserbare uden samtidig at gøre sig skyldig i en naiv empirisme eller realisme kan anses for at være et af de centrale anliggender hos Bruno Latour. Han griber denne opgave an ved at udvide handlingsbegrebet, idet han i sin Aktør-Netværks-Teori også giver artefakterne aktørstatus; de bliver - ligesom de handlende mennesker - til aktanter.

I Reassembling the Social (Latour 2005a) forsøger han at bestemme det sociale på en grundlæggende ny måde, nemlig som en relationssammenhæng, der kan sættes sammen af forskellige typer aktanter. Dermed tildeles artefakterne og produktionen af artefakter en vigtig rolle i konstitutionen af sociale rum. Simple eksempler er redskaber som køleskabet, der har fortrængt andre kulturteknikker til opbevaring (tørring eller henkogning af grøntsager og frugt) og dermed har overtaget de kompetencer, der engang blev udøvet af mennesker. Og Karin Knorr-Cetina (2001), som også bidrager til den STS-orienterede del af praksisteorier, analyserer den 
ikke-habituelle erfaring, altså dér hvor rutiner gennembrydes, som en differentieret praksis, hvor subjekt og objekt stilles i et relationelt forhold til hinanden, der samtidig muliggør kreativitet. Også forskningens genstand indtager en ny rolle, denne gang som forskningens objekter, som - og her er en sammenligning med Dewey igen oplagt - er kendetegnet ved, at de er uafsluttede og ligefrem modsætter sig en entydig identificering. Hvis de ikke var det, sådan kan man med Dewey reformulere Knorr-Cetinas ansats, så ville genstanden simpelthen miste sin videnskabelige relevans, den ville ikke længere være af interesse. I det følgende afsnit vil jeg vise, hvordan Deweys pragmatiske forståelse af erfaring kan bidrage til denne "practical turn".

Dewey stiller erfaring på samme niveau som begreberne kultur og historie og gør det dermed fra starten klart, at erfaring på ingen måde kan begrænses til et individs private, subjektive erfaring. Ganske vist er det individer, der gør erfaringer, men i erfaringer er indeholdt kulturelle, sociale, historiske og kognitive elementer af intersubjektiv natur. Dewey kendetegner erfaring - og dermed rekurrerer han til James - som "dobbeltløbet": "Erfaringen er dobbeltlobet forstået på den måde, at den i sin primære helhed ikke kender til nogen adskillelse mellem akt og materiale, mellem subjekt og objekt, men indeholder begge i en uanalyseret totalitet" (Dewey 1988:18). Totaliteten er dermed forestillet som del af organismens interaktion med omverdenen.

Deweys erfaringsbegreb indeholder mindst tre betydninger: for det første det, som Dewey kalder primærerfaring, for det andet erfaring som det at have erfaring med noget og for det tredje en refleksiv erfaring. For empirismekritikken er især erfaring i den første betydning problematisk. Denne primærerfaring kan man fortolke som en omfattende somatisk erfaring uden funderingspligter. Et eksempel på primærerfaring giver Dewey i sin kunstteori:

"Der er så den storm, der i sin heftighed, som vi oplevede den, syntes at forene alt det i sig, som udgør en storm; en i sig selv lukket erfaring, der stikker frem, fordi den adskiller sig fra det forudgående og det efterfølgende” (Dewey 1980:48).

Denne erfaring opviser altså kvaliteter, der erfares som specifikke, fx somatisk. Selvfølgelig er også denne erfaring af stormen formidlet, forstået på den måde, at der går tidligere erfaringer forud for den og at der forud for det subjektive indtryk ligger tidligere vurderinger og selektionsprincip- 
per. Primærerfaringens funktion hos Dewey er imidlertid en anden end den at overtage retfærdiggørelsespligter for diskursive domme. Snarere overtager primærerfaringen en heuristisk funktion for interaktionen med verden, eller som Richard Shusterman fremhæver, gør den det muligt "at etablere og forbedre kvaliteten af den umiddelbare erfaring som et praktisk og nyttigt redskab" (Shusterman 1997:167). Deraf også betoningen af erfaringens sanselige og kropslige elementer. Primærerfaring og viden ligger på forskellige niveauer, og sikret viden består ikke i en adækvat oversættelse af erfaring til sande domme. Den situationelle primærerfaring udgør startpunktet for den forskende nysgerrighed, for undren, for ikkeviden. Derfor er det heller ikke mærkværdigt, at primærerfaringen netop behandles i rammerne af analysen af forskningsprocessen i Deweys Logic: The Theory of Inquiry (Dewey 1986).

For det andet forstår Dewey erfaring som det at have erfaring med noget, $\mathrm{fx}$ at cykle eller at bage en kage. Her har vi på den ene side en bogstavelig opskriftviden, altså en erfaring, der er diskursivt beskrivelig og har en præskriptiv funktion, men på den anden side også det, som Polanyi har sammenfattet som tavs viden. Erfaring af denne praktiske og kropsliggjorte, men ikke-sproglige slags, er præsent på tre måder: for det første i værktøj, for det andet $\mathrm{i}$ artefaktet eller produktet og for det tredje i den handlende. Hammeren eller støbeformen er de værktøjer, som det succesfulde resultat af tidligere erfaring er sedimenteret i, skulpturen eller cyklen er realiseringerne, erfaringens genstandslighed, og i kunstneren, hvis hænder ved, hvordan stenen behandles rigtigt, er denne erfaring inkarneret og kan aktualiseres, men også varieres. De her omtalte videnstyper, som virker med i erfaringen, er af ikke-propositionel art. Interessant er her særlig den slags erfaring, som samtidig er opbevaret i værktøjerne og i produkterne og som aktualiseres i de forskellige realisationer. Aktualiseringen sker ifølge Dewey ikke efter en skematisk regel, men derimod i selve handlingsrelationen via en problematisering af midlerne og deres konsekvenser, såvel som af en problematisering af formål og en, som Hans Joas har formuleret det, "reciprocitet af mål og midler"(Joas 1992: 227).

Den tredje anvendelsesmåde af erfaring som refleksiv erfaring har Hegelianske træk: i erfaringen af vores handlinger og med objekter gør vi også en erfaring med os selv - vinder så at sige viden om os selv. Inden for rammerne af beskrivelsen af forskningsprocessen er dette for Dewey den kontrollerede produktion af viden, f.eks. med eksperimenter, statistiske undersøgelser og andre relevante metoder. Denne erfaring ligger på 
diskursivitetsniveauet, for vi har at gøre med afprøvede og intersubjektivt delte erfaringslagre, når vi indsætter fx begreber, teorier eller metoder til løsning af et defineret problem. Også her handler det igen om en situation, hvis præcise bestemmelse denne gang har den specifikke forandring af de enkelte elementer som mål. Dewey taler i sin kunstteori om, at vi gør en erfaring, når "materialet, som er blevet erfaret, gennemløber en udvikling hen imod fuldendelse" (Dewey 1980: 47). Og med fuldendelse forstår han en betydningsfuld handlingskæde, f.eks. når en løsning på et problem er fundet, eller når et måltid har fundet sin afslutning. Den refleksive erfaring, den gjorte erfaring har altså også en relation til vores viden om os selv.

Det pragmatiske erfaringsbegreb unddrager sig dermed spørgsmålet om diskursivt eller ik.ke-diskursivt, da det ikke direkte overtager nogle epistemologiske retfærdiggørelsespligter for de diskursive domme eller beskrivelsen af erfaringsindhold. Derudover henviser erfaringsbegrebet til en situation i hvilken erfaring bygger på et net af kontekster, beskrivelser, forklaringer og symbolske verdener, som vore handlinger er indlejret i og hvorfra de trækker betydning. Erfaring og praksisser er altså gensidigt relateret til hinanden.

\section{Perspektivering: erfaring og artefakter}

Den tese, som her forfølges, lader sig kort sammenfatte således: Det pragmatiske erfaringsbegreb, som det er konceptualiseret af Dewey, muliggør et omfattende perspektiv på og en behandling af teknologier og hverdagsgenstande, netop fordi det ikke er epistemologisk indsnævret. Her bidrager Deweys pragmatisme til den praktiske vending med en nuanceret forståelse af erfaring. Men Deweys pragmatisme muliggør også en forandring af selve den filosofiske praksis, en nyorientering af filosofi og teori, som er mere radikal end de andre praksisteorier vil tillade. Jeg behandler i det følgende kort, hvad man kan kalde Deweys konstruktive bidrag til den praktiske vending, for jeg afslutningsvis henviser til den radikale forandring af filosofiens og teoriens rolle som Deweys praksisbegreb implicerer.

Med henblik på konceptualiseringen af tekniske genstande modsætter pragmatismen sig såvel den teknologiske som den sociale determinisme. John Dewey har dog ikke egentlig udviklet en detaljeret teknikfilosofi, og hans instrumentalisme (Eldridge 1998: 68) kan synes noget naiv i forhold til de komplekse analyser i de undersøgelser, der foretages i socialvidenskabernes teknologi-studie-tradition. Og dog indbefatter Deweys instru- 
mentalisme ikke blot en analyse af teknologi eller tekniske genstande som middel til at opnå fastlagte mål, men også refleksioner over videnskabens og teknologiens mål. Hermed kunne Dewey også bidrage til nyere udviklinger af Aktør-Netværk-Teorien, hvor det normative spørgsmål dukker op som et problem i forbindelse med perspektivernes pluralisme og hvor teoriens egen praksis skal bestemmes på ny (Gad \& Jensen 2010). Pragmatismen er ikke teknologifjendtlig, men tenderer heller ikke mod en hypertrofisk overvurdering af teknologiens muligheder. Videnskabens og teknologiudviklingens mål, betingelsesrammer og midler bliver af Dewey på ingen måde betragtet som neutrale. Hans instrumentalisme er, som bl.a. Larry A. Hickmann (Hickmann 1992) fremhæver, båret af en stærkt normativ baggrund, der retter sig mod en demokratisering af videnskab. Den videnskabelige praksis konceptualiseres som en kooperativ praksis, i hvilken analogierne til demokratiets eksperimentfællesskab ikke er til at overse. Den ensomme ingeniør erstattes af de forskendes kooperative fællesskab, som igen står $\mathrm{i}$ et åbent og ofte konfliktpræget forhold til den kritiske offentlighed - en udvikling i nyere tid som Nowotny, Scott og Gibbons (Nowotny, Scott \& Gibbons 2001) har behandlet med deres analyse af overgangen fra et vidensbegreb, der orienterer sig mod grundforskning, til en vidensforståelse, der retter sig mod anvendelse og nytteorientering.

Sammenfattende kan man fastholde, at Deweys pragmatisme stemmer overens med den praktiske vendings forskellige teorier i det forhold, at aktører, strukturer og genstande skal betragtes som praksisser - eller med Deweys terminologi som erfaringer og erfaringskontekster. En mulighed for at afkode disse komplekse sammenhænge giver Deweys transformation af middel-mål-skemaet. Med den følgende fremstilling forsøger jeg at skitsere en spørgeretning, som efter min vurdering er et egnet bidrag til at videreudvikle den pragmatiske tænkning og den praktiske vending.

I almindelighed antager vi at tekniske artefakter enten selv er produkter af teknisk fremstillen eller er værktøj eller midler til forfølgelse af bestemte formål. Dewey skelner mellem et ydre og et indre middel (Dewey 1980: 232). Et eksempel på et ydre middel er vaskemaskinen, som har det formål, at vaske vasketøjet rent. Som eksempel på et indre middel kan gives kunsten; farven er ganske vist et middel til at fremstille billedet, men den er ikke noget ydre i forhold til billedet. Vores vasketøj kan vi lige så godt vaske $i$ hånden - med nogen anstrengelse med samme resultat. Det gælder ikke for farven - en anden farve og enhver afvigelse i brug af farven betyder også et andet billede. Det er nu afgørende, at det for Dewey 
på ingen måde er fastlagt, hvad der gælder som ydre eller indre middel. Vaskemaskinen kan f.eks i et eksperimentelt teaterstykke blive til et indre middel. En lignende analyse med hensyn til formålsbestemmelse kan man foretage af udnyttelsen af mobiltelefonen. Succesen for SMS - egentlig en udnyttelsesmåde som er fuldstændig fremmed for telefonen (hvem skulle have troet at telefonen med sådan succes ville blive benyttet til at skrive beskeder?) - er fra Deweys synspunkt en kreativ anvendelse af midler med en ny definition af formålet. Dermed er telefonen ikke bare udnyttet anderledes, men med en ny praksis, der er opstået ud af hverdagskommunikationen, opstår nye tekniske anvendelser og en ny type kommunikationsteknologi. Deweys analyseredskaber 'indre' og 'ydre' middel kan bruges for at forstå og analysere, men også for at fremme innovationsprocesser. Nye erfaringsrum bliver erobret gennem teknisk handlen, men også med handlen med teknik, altså dens brug. Dette bliver muliggjort gennem den fleksible vekselvirkning mellem midler og mål, som Dewey har redegjort for. Tekniske artefakter fastlægger hverken erfaringsrum eller handlingsmuligheder på deterministisk vis. Et ikke-epistemologisk erfaringsbegreb kan mobilisere et element i en sådan pragmatisk teori, i hvilken relevante erfaringsrum, f.eks. mobilkulturens rum analyseres, hvor der må tages hensyn til ressourcer og begrænsninger på samme vis. Den pragmatiske etos transformerer dermed billedet af den klassiske filosofi om mennesket som blot vidende til et menneskebillede, hvor handlen, erfaring og artefakter bringes i et produktivt forhold.

En videre og mere radikal konsekvens af den pragmatiske behandling af praksis og erfaring ville være en kooperation mellem de tekniske videnskaber og filosofien såvel som de socialvidenskaber, der har til formål at udvikle teknologier og tekniske genstande. Dermed ville filosofien og socialvidenskaberne på en radikal måde træde ind i en praksissammenhæng og endegyldigt lade den kontemplative vidensforståelse bag sig. Dermed ville den pragmatiske forståelse af at beskæftige sig med teknologi også adskille sig fra praksisteorierne, der ganske vist har taget et skridt hen imod en analyse af praksisser, men viger tilbage for det næste skridt hen imod en direkte andel i produktionen af tekniske genstande. Her gælder nemlig stadig den problematisk opdelingen i kritisk-distanceret forskning på den ene side og anvendelsesorienteret nytteforskning på den anden side. Dog frembyder nyere hybridvidenskaber såsom service design eller 
fag som techno-antropologi (Aalborg Universitet) de første udgangspunkter for en sådan aktiv anvendelse af filosofisk refleksion. Teoretiske begreber og ideer bliver her underlagt en streng operationalisering, der gør alvor af den pragmatiske devise om, at et begreb først er forstået, når man ser konsekvenserne af dets arbejde.

Jeg takker Anna Lena Sandberg for oversattelsen fra den tyske original. Jeg takker desuden begge reviewere fra Slagmark, som har givet mig konstruktiv kritik og vardifulde henvisninger. En sarlig tak går til Martin Ejsing Christensen, både for korrekturlasning og for hans tålmodighed.

\section{Note}

1 Et godt eksempel på en eksperimentalistisk indstilling i hverdagen er at lave mad efter en opskrift. Det er en proces, der er forbundet med kontingens og usikkerheder. En eksperimenterende indstilling er dermed en nødvendig bestanddel af "opskriftmadlavning", selvom erfaring her dog også kan beskytte imod grandiøst mislykkede eksperimenter.

\section{Litteratur}

Bernstein, Richard (1989): "Pragmatism, Pluralism and the Healing of Wounds" i APA Proceedings, vol. 63, no. 3, s. 5-18.

Bourdieu, Pierre (2000): Pascalian Meditations, Stanford: Stanford University Press.

Dewey, John (1980): Kunst als Erfahrung, Frankfurt a. M.: Suhrkamp.

Dewey, John (1986): Logic: The Theory of Inquiry, Later Works vol. 12, Carbondale and Edwardsville: Southern Illinois University Press.

Dewey, John (1988): Experience and Nature, Later Works vol. 1, Carbondale and Edwardsville: Southern Illinois University Press.

Dewey, John (1991): The Public and Its Problems, Athens: Ohio University Press.

Eldridge, Michael (1998): Transforming Experience. John Dewey's Cultural Instrumentalism, Nashville: Vanderbilt University Press.

Gad, Christopher \& Jensen, Casper Bruun (2010): “On the Consequences of PostANT" i Science, Technology \& Human Values, vol. 35,1, s. 55 - 80.

Gimmler, Antje (2004): "Hegel as Pragmatist" i Bill Egginton et al. (red.), The Pragmatic Turn in Philosophy, Albany N.Y.: SUNY, s. 47-66.

Hickman, Larry A. (1992): John Dewey's Pragmatic Technology, Bloomington: Indiana University Press.

Joas, Hans (1992): Die Kreativität des Handelns, Frankfurt a. M: Suhrkamp. 
Knorr Cetina, Karin (2001), "Objectual practice” i Th. Schatzki, K. Knorr Cetina \& E.v. Savigny (red.): The Practice Turn in Contemporary Theory, London: Routledge, s. 175-188.

Latour, Bruno (2005a): Reassembling the Social. An Introduction to Actor-Network-Theory, Oxford: Oxford University Press.

Latour, Bruno (2005b): "From Realpolitik to Dingpolitik or How to Make Things Public” i B. Latour \& P. Weibel (red.), Making Things Public. Atmospheres of Democracy, Cambridge Mass.: MIT Press.

Nowotny, Helga, Scott,Peter \& Gibbons, Michael (2001): Re-Tbinking Science. Knowledge and the Public in an Age of Uncertainty, Cambridge: Cambridge University Press.

Reckwitz, Andreas (2002): “Toward a Theory of Social Practices" i European Journal of Social Theory, Vol. 2, s. 243-263.

Rorty, Richard (1990): „Pragmatismus, Davidson und der Wahrheitsbegriff“ i E. Picardi \& J. Schulte (red.), Die Wabrheit der Interpretation, Frankfurt a. M.: Suhrkamp.

Rorty, Richard (1996)"'Idealizations, Foundations, and Social Practices" i S. Benhabib (red.), Democracy and Difference, Princeton: Princeton University Press, s. 333-335.

Rorty, Richard (1997):“ Relativismus: Finden und Machen“ i A.Gimmler, M.Sandbothe \& W.Ch. Zimmerli (red.,: Die Wiederentdeckung der Zeit, Darmstadt: Wissenschaftliche Buchgesellschaft, s. 9-26.

Schatzki, R. Theodore, Knorr-Cetina, Karin \& Savigny, Eike von (red.) (2001a): The Practice Turn in Contemporary Theory, London: Routledge.

Schatzki, R. Theodore (2001b): "Introduction: Practice Theory” i Th. R. Schatzki, K. Knorr Cetina \& E.v. Savigny (red.), The Practice Turn in Contemporary Theory, London: Routledge, s. 10-23.

Sellars, Wilfrid (1999): Der Empirismus und die Philosophie des Geistes, Paderborn: Mentis. Shusterman, Richard (1997): "Somatic Experience - Foundation or Reconstruction" i R. Shusterman: Practicing Philosophy: Pragmatism and the Philosophical Life, New York/ London: Routledge, s. 157-178. 
